\title{
Compare the Effect of Mental Practice Traditional, Pettlep and Physical on Basketball Free Throw Skill
}

\author{
Mohsen Vakil Zadeh ${ }^{1}$, Frahnaz Ayati Zadeh ${ }^{2}$, Hamid Abbasi ${ }^{3}$ \\ 1. Mohsen Vakil Zadeh, (M.A Student) Yazd University, Yazd, Iran \\ 2. Frahnaz Ayati Zadeh, (Ph.D) Yazd University, Yazd, Iran \\ 3. Hamid Abbasi, (Ph.D) Yazd University, Yazd, Iran
}

\section{ARTICLE INFO}

Received October 2017

Accepted June 2018

\section{KEYWORDS:}

Mental practice traditional

Mental practice Pettlep

Physical practice

Basketball free throw skill

CITE:

Vakil Zadeh, Ayati Zadeh, Abbasi, Compare the Effect of Mental Practice Traditional, Pettlep and Physical on Basketball Free Throw Skill, Research in sport management \& motor behavior, 2020: 9(18):166-177

\section{ABSTRACT}

One of The mental skills that suggested by psychologists for athletes is mental imagery. Imagery is a conscious internal process that mimics real-life experience in absence of sensory perception experience. The aim of this study was to compare the effects of traditional mental practice, Pettlep and physical practice on basketball free throw skill. In this study 40 participant after evaluation were randomly divided into traditional (10), Pettlep(10), physical(10) and control(10) groups. For statistical analysis t-test, ANOVA, Tukey post hoc test was used. For statistical analysis, t-test used to evaluate changes within the group, variance used for investigate out-group changes, Levene test used for normal distribution of data and the Tukey post hoc used to determine the differences and their position within the group and between-group. Statistical analysis showed that traditional mental exercises did not show improvement in learning than pre-test $(p>0 / 05)$. But physical exercise showed significant results than traditional mental practice $(p<0 / 05)$. Results also demonstrated that Pettlep mental practice group showed significant difference than physical exercise $(p<0 / 5)$. According to the results of this study Pettlep mental workout is more effective than traditional mental and physical practice. 


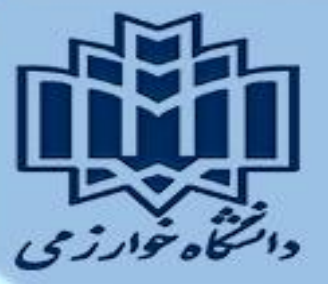

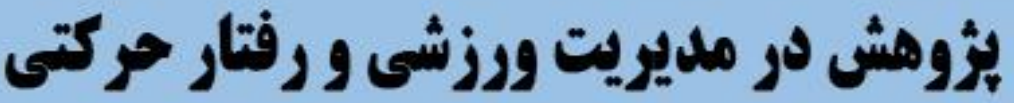

\section{مقايسه تاثير روش هاى تمرين ذهنى سنتى، يتلٍ و بدنى بر يادكيرى مهارت يرقاب آزاد بسكتبال}

محسن وكيل زاده'، فرحناز آيتى زاده**`، حميد عباسى

$$
\begin{aligned}
& \text { 1. دانشجوى كارشناسى ارشد رفتار حركتى، دانشگاه يزد، يزد، ايران }
\end{aligned}
$$

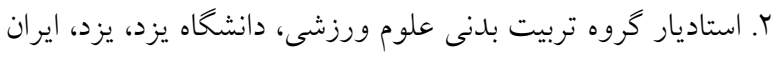

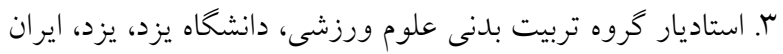
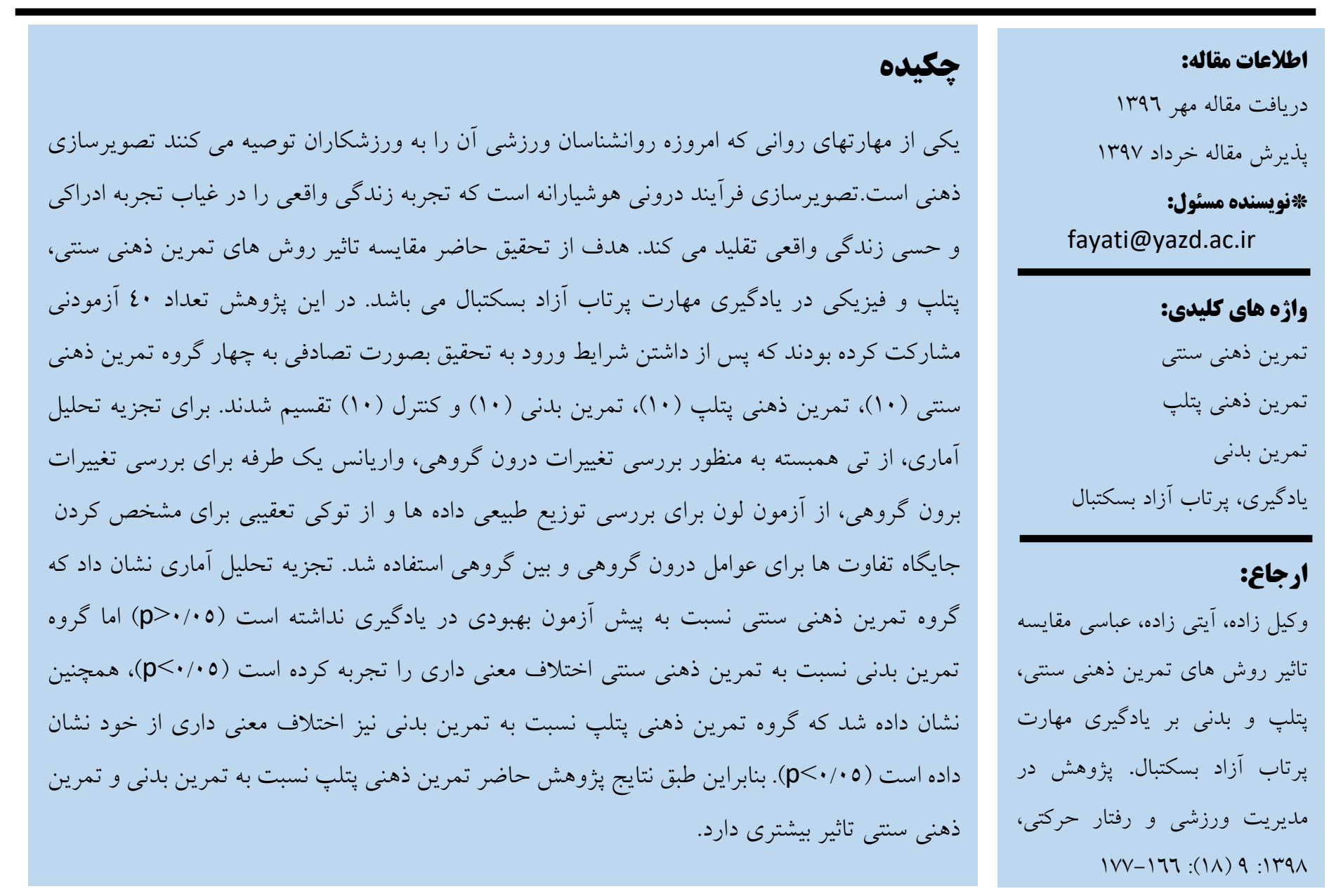

https://jrsm.khu.ac.ir/ 


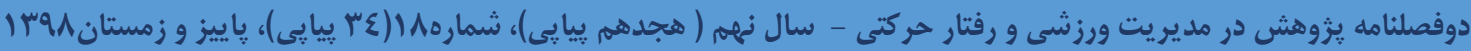

\section{مقدمه}

بشر از آغاز تا بايان زندگى خود با صورت هاى مختلف ياد گيرى در ارتباط است. يادگيرى به طور بيوسته با انسان همراه

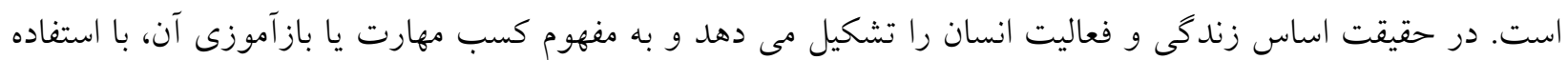
از تمرين است ( (1). تمرين به صورت هاى مختلفى مى تواند انجام شود كه يك نوع بسيار معمول آن تمرين بلدنى است،

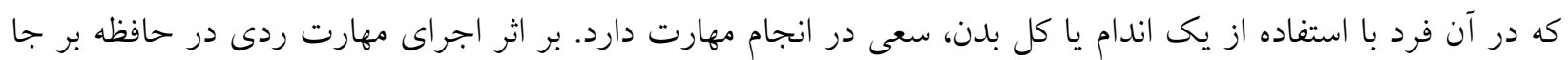
مى ماند كه در انتها منجر به ياد گيرى مى شود (T). نوع ديخرى از تمرين، تمرين ذهنى است. با وجود ده ها سال يزوهش مستند در خصوص فوايد تداخلات تصوير سازى ذهنى، محققان و دست اندر كاران به ادامه ى كار براى توسعه ى تمرينات تصوير سازى ذهنى برداخته اند (r، 1). مطابق با نظر مربيان، تصوير سازى ذهنى، مفيد ترين مهارت روانى است كه يك اجرا كننده مى تواند از آن استفاده و بيش از هر روش ديخر براى بهبود عملكرد به كار

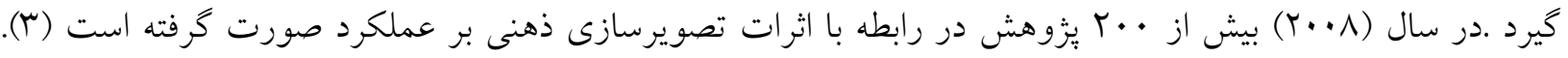
ورزشكاران در تمام سطوح از تصوير سازى براى انواع دلايل شناختى و انخيزشى استفاده مى كنند و ورزشكاران نخبه نسبت به ورزشكاران سطح بايين از تصويرسازى نظام مند تر و گسترده تر استفاده مى كنند. تصويرسازى ذهنى شامل تجسم يا مرور شناختى حركت بدون اجرايى فيزيكى است كه نمايش مكرر اثر بخش بودن آن، اين روش را به عنوان راهبردى با ارزش براى ارتقاء عملكرد معرفى مى كند (ع). تصويرسازى ذهنى يك اجراى موفق، منجر به افزايش خود سودمندى در يك تكليف مى شود و مى تواند با عملكرد مثبت خود، رقابتهاى بعدى را تحت تأثير قرار دهد (0). تصويرسازى ذهنى در زمينه هاى مختلف براى توليد عملكرد بهينه در ارتباط با ياد گيرى يكى مهارت جديل، تمرين بين

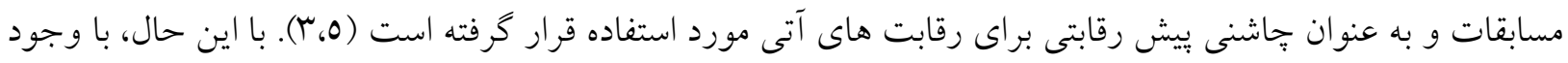
كذشت يكى قرن از تحقيقات تصويرسازى، روش رسيدن به بهينه سازى عملكرد ورزشى بسيار متغير و بحث برانخيز باقى مانده است (Y). از عوامل مؤثر در اثربخشى تصويرسازى ذهنى مى توان به ماهيت تكليف، سطح مهارت شركت كننده

$$
\text { و توانايى تصوير سازى ذهنى اشاره كرد (r). }
$$

همجنين ساكت (عسه (1) در نظريه ياد گيرى نمادين بيان مى كند كه تمرين ذهنى باعث رمز كذارى حركات مورد نياز جهت انجام مهارت در مغز مى شود. اين رمز كذارى حركات در مغز با خلق يك برنامه حركتى در سيستم اعصاب مركزى و واكنش در اين برنامه باعث تسهيل مهارت حركتى مى گردد (0). نظريه برابرى عملكردى در زمينه تصويرسازى بيان مى كند كه اولا، تصويرسازى از نظر عملكردى همسان با ادراى است، همجنين هردو داراى مسيرهاى عصبى مشتركى هستند، دوم اينكه تمرين ذهنى از لحاظ عملكردى با تمرين بدنى همسان است، زيرا هنگام تصويرسازى دقيقا همان

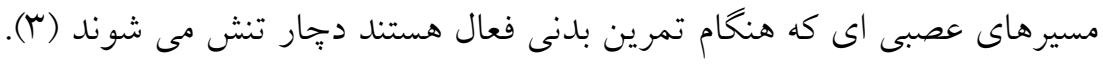




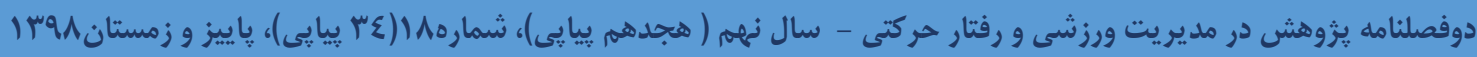

تصويرسازى بر دو نوع است. اولين و ساده ترين شيوه تصويرسازى، مدل تصويرسازى سنتى است. در تصويرسازى سنتى فرد در محيطى آرام و به دور از هيجان به تصور حركات مى بردازد و اجراى موفقيت آميز مهارت را در غياب حركت بدنى در ذهن مجسم مى كند. در طى سالها مدلهاى مختلف تصويرسازى به كار كرفته شده است. اما همواره اين سوال وجود داشته است كه كدام ساختار در مداخلات تصويرسازى بيشترين اثر را دارد. براى ياسخ گويى به اين سوال، مدل

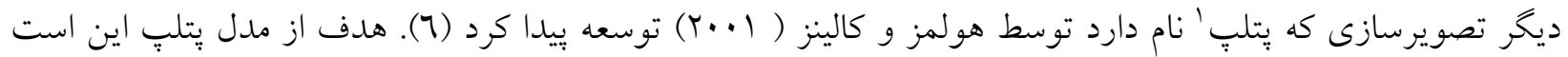
كه شرايط انجام تصويرسازى تا حد ممكن مشابه با شرايط اجراى حركت واقعى باشد. آنها مداخلات زير را به عنوان ملاكى در تصويرسازى حركتى تعريف كردند: مولفه هاى فيزيكى، محيطى، تكليف ، زمان بندى، ياد گيرى، هيجان و ديدكاه

كه از تركيب حروف اول اين كلمات يتلٍٍ ياد مى شود (7).

مولفه فيزيكى مدل بِلٍٍ به مشابهت وضعيت جسمانى شركت كنند كان طى انجام تصويرسازى ذهنى و تكليف واقعى اشاره دارد. مؤلفه محيطى از اين مدل، شبيه سازى بين محيط رقابتى و محيط تصويرسازى ذهنى است. مؤلفه مي مربوط به تكليف (مهارت مورد نظر) عامل مهمى است، به اين صورت كه مهارتى كه تصور و تجسم مى شود، بايد با مهارتى كه در واقعيت بايد انجام مى كيرد، يكسان باشد (7). زمانبندى، اغلب در شرايط مسابقه و اجراى مهارتهاى خاص بسيار اهميت دارد بنابر اين عملكرد معادل زمانى رخ مى دهد كه تصويرسازى نيز با همان سرعت انجام شود (V). مولفه ياد كيرى مدل يتلٍ به انطباق تصويرسازى با ميزان يادكيرى فرد ارتباط دارد. در مولفهُ هيجان، به منظور دستيابى به عملكرد بهينه،

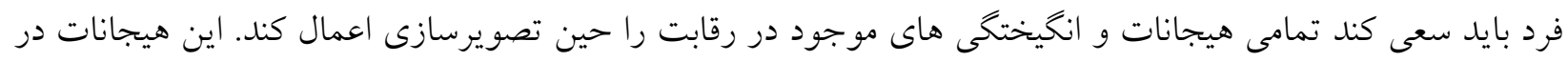

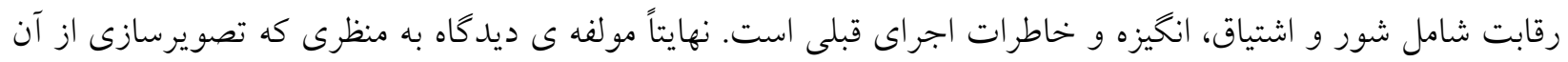
مشاهده مى شود (تصويرسازى درونى و بيرونى) برمى گردد (7). مدل تصويرسازى ذهنى يتلٍٍ بر اساس تحقيقات علوم اعصاب معرفى شده و نشان مى دهد كه هميوشانى هاى قابل توجهى در مناطق فعال مغز در طول انجام تصويرسازى ذهنى يك حركت جنبشى و اجراى واقعى همان حركت وجود

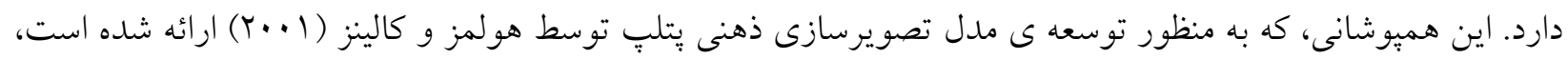
"هم ارزى كاركردى " ناميده مى شود. با توجه به اظهارات يزوهشخران، استفاده از تصويرسازى ذهنى به دليل شبيه سازى حركاتى كه بين اجراى فيزيكى و تصويرسازى ذهنى مشترى هستند، مى تواند عملكرد را تسهيل كند (7). تفاوت نسخه هاى تصويرسازى ذهنى يتلٍ با مدل سنتى تصويرسازى ذهنى، كنجاندن توضيحات جنبشى فرد از تكليف حركتى است، در حالى كه نسخه هاى سنتى عمدتاً بر آنجه شركت كننده در طول تكليف مى بيند، تمركز دارد. به عبارتى ديخر، در مدل يتلب حواس بيشترى درگير خواهد شد كه براساس نظر هولمز و كالينز، هر پهه ميزان در گيرى حواس بيشتر شود، موجب افزايش هم ارزى كاركردى مى شود. تصويرسازى ذهنى به صورت سنتى در محيطى دور از محيط رقابتى و همجنين بدون

1. Physical‘ Environmental، Task، Timing، Learning، Emotional‘ Perspective

https://jrsm.khu.ac.ir/ 


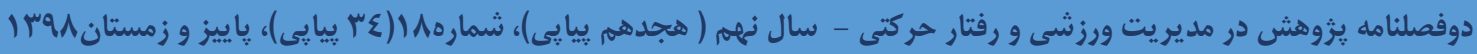

استفاده از ابزارى كه در ميدان ورزشى استفاده مى شود، انجام مى كيرد و اغلب توجه كمى به حس جنبشى مى شود و تأكيد اصلى بر جنبه هاى ديدارى تصويرسازى ذهنى (م).

همجنين طبق نظر محققين، مدل يتلٍ براى كمك به تسهيل بهبود در يك فعاليت جسمانى در هنگامى كه امكان فعاليت بيشتر و بهتر مقدور نيست، از جمله درهنغام آسيب و يا محدوديت دسترسى به اماكن ورزشى استفاده مى شود. توازن عملكرد در آرام سازى بدنى مؤثر نيست و حتى به نظر مى رسد كه كاملاً با حالت بدنى اجر ایى ورزشكاران مغايرت داشته باشد. به نظر آنها تصويرسازى ذهنى زمانى مؤثرتر است كه تمامى حواس دركير باشند و و احساسات جنبشى درى درخلال اجراهاى واقعى مهارت تجربه شوند (7).

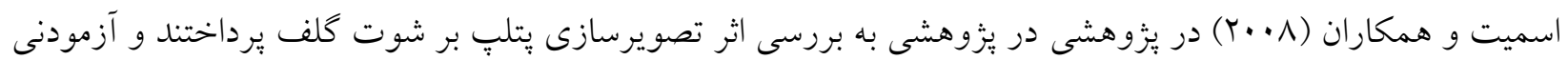

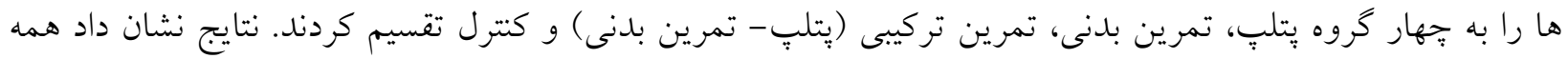

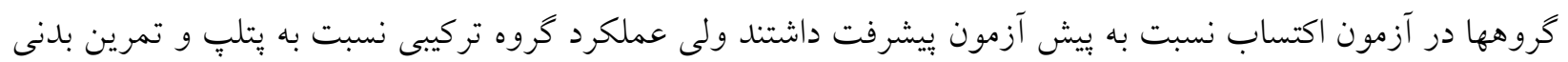
بهتر بود. با اين حال تفاوت معنادارى بين گروه يتلب و تمرين بدنى وجود نداشت (9).

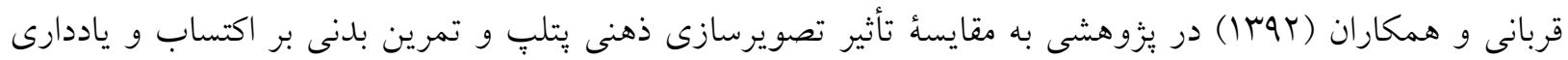

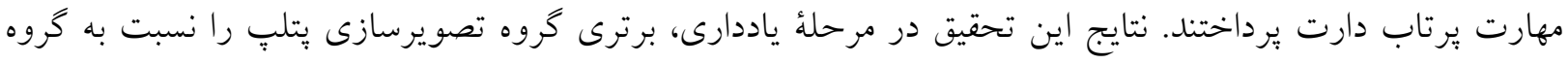
تمرين بدنى نشان داد (·)

در سالهاى اخير محققان به بررسى تأثير تصويرسازى يتلٍ بر عملكرد حركتى و اينكه جطور فرايند تصويرسازى به

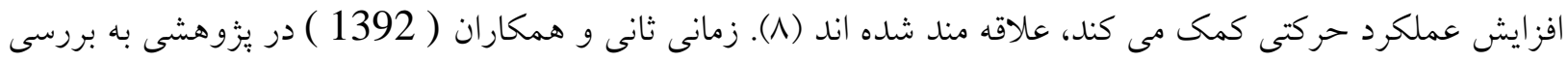
سرعت هاى مختلف تصويرسازى حركتى بر دريبل فوتبال بازيكنان ماهر يرداختند. نتايج نشان داد تفاوت معنادارى بين كروهها در متغير وابسته وجود دارد، به طورى كه گروه تصويرسازى سريع، زمان اجراى سريعترى نسبت به دو گروه ديخر داشت .اين يزوهش در حمايت از مؤلفهُ زمانبندى الكوى يتلٍ انجام گرفته بود (11).

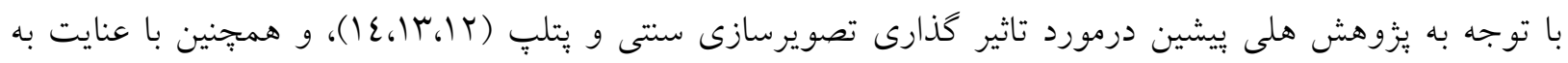

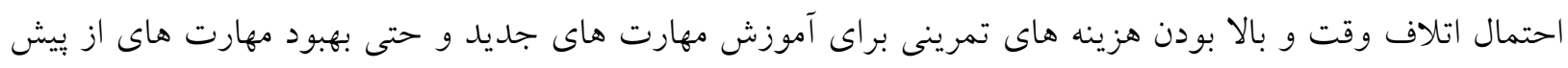
آموخته شده و همجنين جلو كيرى از به هدر رفتن استعدادهاى بالقوهى نو آموزان و كشف بهترين روش هاى تمرينى، محققان در صدد گزينش مناسب ترين روش براى ورزشكاران هستند كه اين يزّوهش نيز كه به منظور مقايسه ى تصويرسازى ذهنى سنتى، يتلٍٍ و تمرين بدنى در فرايند اكتساب و ياددارى تكليف يرتاب آزاد بسكتبال به نو آموزان است، بر آن است تا كامى در همين راستا بردارد. 


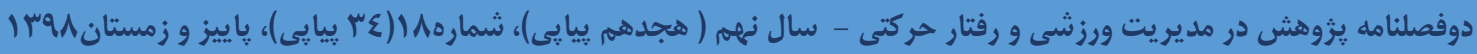

\section{روش تحقيق:}

اين تحقيق از نظر شيوه جمع آورى اطلاعات نيمه تجربى، و با استفاده از طرح ييش آزمون و يس آزمون با گروه كنترل مى باشد و از نظر هدف كاربردى است. جهت سنجش توانايى تصويرسازى افراد از يرسشنامه توانايى قابليت تصوير سازى ذهنى حركت MIQ-R هال و مارتين (199V) كه توسط سهرابى و همكاران (1MNM) اعتبار يابى شده است استفاده شد. اين يرسشنامه شامل هشت سؤال و دو خرده مقياس حركتى و بينايى است و براى هر خرده مقياس جهار سؤال در نظر گرفته شده، كه هر سوال داراى V گزينه مى باشد و طبق گزينه ها به افراد امتياز داده مى شود. ميزان اعتبار سازه

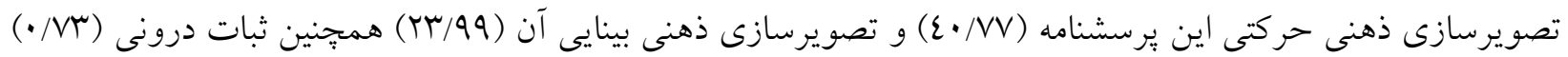

$$
\text { و بايايى زمانى اين :برسشنامه (NVV•) درصد گزارش شده است (10). }
$$

جامعه آمارى اين مطالعه دانش آموزان يُر دبيرستانى شهرستان بشرويه، و نمونه آمارى اين تحقيق را تعداد •ع نفر با دامنه سنى 17 - آس سال كه همكى از يرسشنامه تجديد نظر شده تصويرسازى حركت هال و مارتين(199V) (10) امتياز لازم را بدست آورده بودند و هيج كونه سابقه ى قبلى در ورزش بسكتبال را نداشتند را تشكيل دادند.

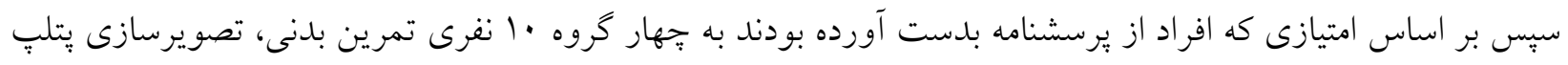

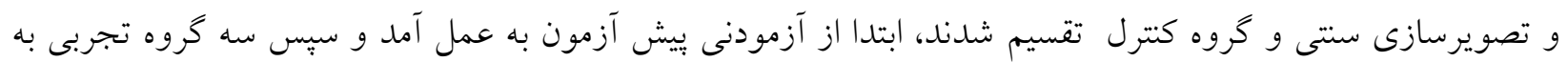
مدت 7 هفته و هر هفته Y جلسه مطابق برنامه خود مشغول تمرين بودند و بر روى گروه كنترل هيج كونه متغير تمرينى اجرا نشد. برنامه تمرينى گروه ها بدين صورت بود كه: گروه فيزيكى ·ل يرتاب به سمت سبد بسكتبال انجام ميدادند. كروه تصويرسازى ذهنى يُتٍٍ با تاكيد بر هفت فاكتور اين مدل، (با لباس و كفش ورزشى و توبٍ در دست داشتند، در محل سالن ورزشى، آكاهى داشتن نسبت به مهارت ملاك، زمان قانونى براى برتاب، مرحله يادكيرى، و آكاهى داشتن نسبت به هيجانات و جشم انداز تصويرسازى) •( يُرتاب را تصويرسازى مى كردند. گروه تصويرسازى سنتى (در مكانى غير از سالن ورزش) به صورت تمرين ذهنى سنتى ·( يرتاب را به سمت سبد برتاب ميكردند. براى جمع آورى اطلاعات

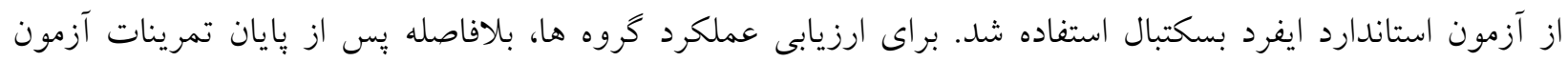

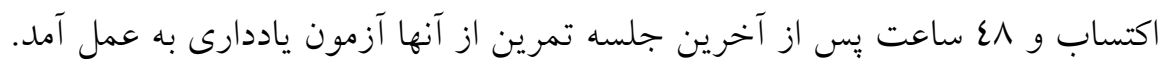

\section{شيوه امتياز دهى:}

هريرتابى كه مستقيم كل شود ع امتياز، اگر به حلقه برخورد كند، و گل شود ب امتياز، اخر به حلقه و تخته برخورد كند و كل شود r امتياز، اكر فقط به تخته برخورد كند و كل شود المتياز و باقى حالت ها امتياز صفر منظورخواهد شد. اعتبار و روايى آزمون ايفرد از نقطه ى پنالتى توسط حمايت طلب ( تحقيق مورد ارزيابى قرار گرفت و اعتبار صورى آن سه ٪ و روايى آن به مقدار عه ٪ محاسبه شد (19). هم:حنين موحدى 


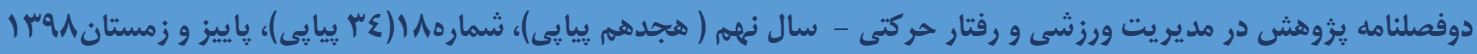

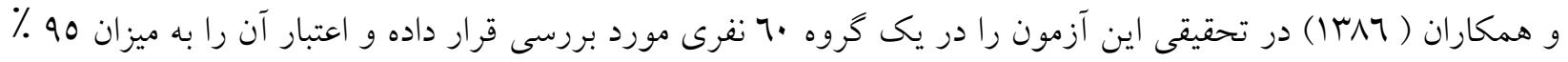

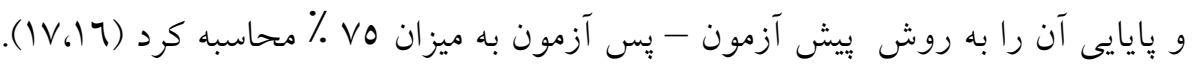

معيار هاى ورود به تحقيق

$$
\text { ا. تحويل رضايت نامه والدين و خود، جهت شركت در يزوهش. }
$$

ז. شركت كنند كان از سلامت كامل جسمانى (توانايى جسمى حركتى) برخوردار باشند. به همين منظور داوطلبانى انتخاب شدند كه داراى معلوليت و يا نقص حركتى نباشند.

r. دست برتر همه شركت كنند كان دست راستشان باشد. در رضايت نامه اى كه به داوطلبان داده شد از آنها خاسته شده بود كه دست برتر يا غالب خود را بنويسند. به همين منظور افرادى در يزوهش شركت داده شدند كه دست غالبشان دست راستشان باشد.

ع. شركت كنند كان هيج كونه سابقه ى قبلى در ورزش بسكتبال را نداشته باشند. 0. تمامى شركت كنندكان در تحقيق، از يرسشنامه تصويرسازى حركت تجديد نظر شده هال و مارتين (MIQ-R) نمره بين 0 ع000به دست آورده باشند.

با توجه به معيارهاى ورود به تحقيق و امتيازاتى كه آزمودنى ها از يرسشنامه ها بدست آورده بودند آزمودنى ها در كروههاى مختلف تمرينى همخن شدند.

جهت تجزيه و تحليل آمارى اطلاعات از آمار توصيفى و آمار استنباطى جهت معنى دار بودن يا عدم معنى دار بودن اختلاف امتيازات به دست آمده توسط جهار گروه استفاده شد. از آزمون تحليل واريانس يكى عاملى در جهار گروه نيز براى تعيين اختلاف ميانخين داده ها و از آزمون توكى براى تعيين سطح معنى دارى آنها بهره كرفته شد.

نتايج و يافته هاى تحقيق تغييرات درون كروهى

بررسى و تجزيه تحليل آمارى نتايج زير را به دنبال داشت. در بررسى تغييرات درونگروهى آزمون تى تست در مقايسه

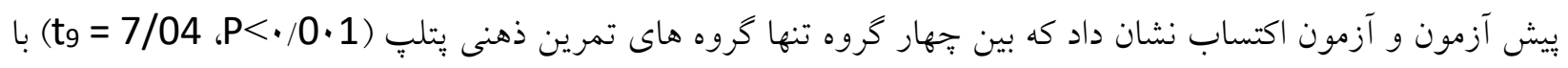

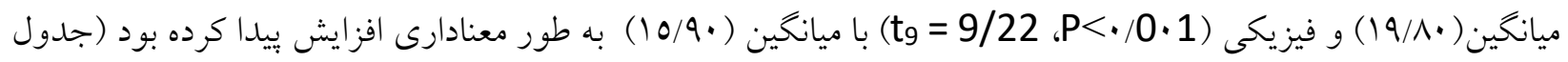


جدول ا-نتايج بررسى تغييرات درون گروهى و برون كروهى

\begin{tabular}{|c|c|c|c|c|c|c|c|}
\hline معنى سطح & $\begin{array}{c}T \\
\text { ياددارى) } \\
\text { - اكتساب) }\end{array}$ & $\begin{array}{c}\text { ياددارى } \\
(M \pm S D)\end{array}$ & معنى دارى & $T$ & $\begin{array}{c}\text { اكتساب } \\
(M \pm S D)\end{array}$ & $\begin{array}{l}\text { ״يش آزمون } \\
(M \pm S D)\end{array}$ & كروه \\
\hline$\cdot \pi \cdot q$ & $-1 / \cdot 1$ & $11 / V \cdot \pm 1 / \mu r$ & $.194 \mathrm{~V}$ & $\cdot / q^{f}$ & $11 / \pi \cdot \pm \cdot / 90$ & $\mid 1 / 9 \cdot \pm 1 / V 1$ & سنتى \\
\hline$\cdot 1 \cdots$ & $-1 Y / T \Lambda$ & $19 / r \cdot \pm 1 / 11$ & $\cdot 1 \cdot \cdots$ & $-V / \cdot F T$ & $10 / 9 \cdot \pm 1 / \%$ & $11 / \pi \cdot \pm 1 / 90$ & فيزيكى \\
\hline$\cdot / \cdots$ & $-r T / V I$ & $r \Delta / \Delta \cdot \pm r / \cdot 1$ & $\cdot 1 \cdots$ & - Q/TKT & $19 / 1 \cdot \pm 1 / 99$ & $11 / 1 \cdot \pm 1 / 99$ & يتلٍ \\
\hline \multirow[t]{3}{*}{.$/ 111$} & $-1 / \mathrm{V}$ & $11 / V \cdot \pm 1 / 49$ & . / १९५ &.$/ 1 r q$ & $11 / 1 \cdot \pm 1 / r v$ & $11 / r \cdot \pm 1 / \Delta \Delta$ & كنترل \\
\hline & & $\begin{array}{c}F_{3,36} \backslash / N / \\
=\end{array}$ & & & $F_{3,36}=r r / 97$ & & \multirow{2}{*}{ مقروهايسه } \\
\hline & & $P<\cdot / \cdot \cdot 1$ & & & $P<\cdot 1 \cdots 1$ & $P>\cdot / \cdot \Delta$ & \\
\hline
\end{tabular}

\section{تغييرات بين كروهى}

همانطور كه در جدول ( ) مشاهده مى شود ميانگين عملكرد كروه هاى سنتى و كنترل در مرحله ياددارى نسبت به مرحله اكتساب در مهارت آزاد بسكتبال بهبود نداشته، و حتى اندكى يسرفت داشته اند. (0•/P>•)، و اين امر مشخص مى كند كه شيوه تمرينى سنتى نهتنها در اكتساب بلكه در ياددارى نيز تأثير معنى دارى در مهارت آزاد بسكتبال نداشته است. با باس

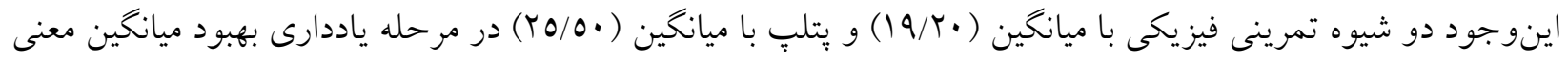

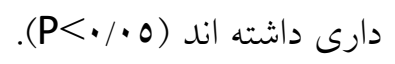

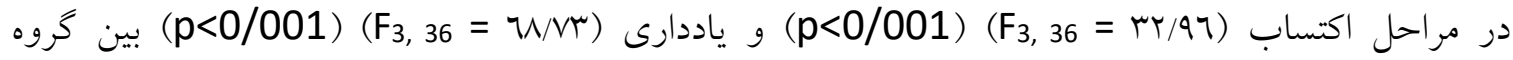
تصويرسازى ذهنى بتلب و فيز يكى با گروه تمرين ذهنى سنتى و كنترل تفاوت معنى دارى وجود مقادير داشت. در مرحله ى اكتساب و ياددارى بين گروه تصويرسازى ذهنى يتلٍ با گروه تمرين بلدنى اختلاف معنى دارى

$$
\text { وجود داشت. }
$$




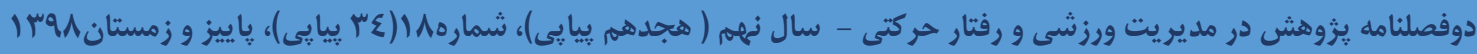

\section{بحث و نتيجه تيرى}

اولين نتيجه يزوهش حاضر اين بود كه گروه تمرين ذهنى سنتى در مراحل اكتساب و ياددارى مهارت ملاك يِيشرفتى بلدست نياورده بود، كه با نتايج تحقيق رايان و سايمون (1911) و مولدر و همكارانش (ع (ب) كه بيان كردند تمرين ذهنى تاثيرى در يادكيرى تكليف حركتى جديد ندارد، همخوانى دارد (19،11). هرجند نوسكى (1990) معتقد است كه عدم

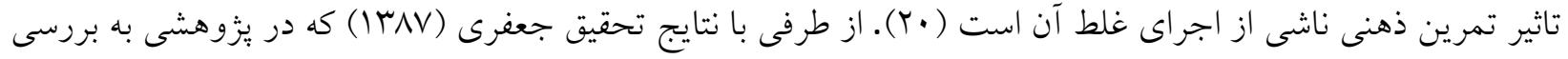

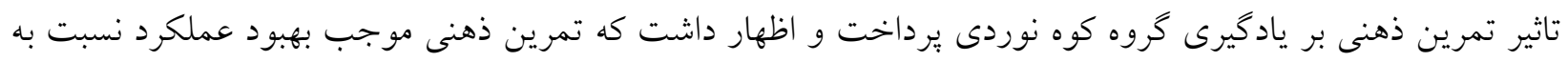
يِيش آزمون مى شود ولى اختلاف معنى دارى با تمرين ذهنى حاصل نمى شود ناهمخوان است (Iال). همجنين با نتايج تحقيق زراعت يِشه و نيازى (rqها) كه بيان كردند كروه تمرين ذهنى نسبت به كروه كنترل عملكرد بهترى داشته است

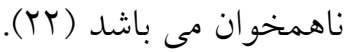

از دلايل احتمالى اين تناقض مى توان به متفاوت بودن مهارت هاى ملاك در دو تحقيق اشاره كرد جر ا كه انجام و يادكيرى مهارت هاى مختلف فاكتورها و شرايط كوناكونى را مى طلبد. همجنين اين تناقض شايد به دليل نبودن برنامهُ حركتى در سيستم مركزى باشد، زيرا آزمودنيهاى اين يزوهش در مراحل اوليةٌ يادكيرى بودند و بازنماى دقيقى از حركت در ذهن نداشتند، بنابراين هنگام تصويرسازى به علت نبود بازنماى دقيق از حركت، براى خلق تصوير روشن از حركت، دجار

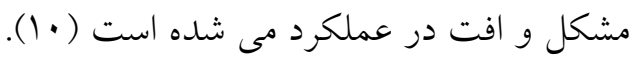

در ادامه نشان داده شد، گروه تمرين ذهنى يتلٍ نسبت به گروه تمرين ذهنى سنتى و گروه تمرين بلدنى در دو مرحله

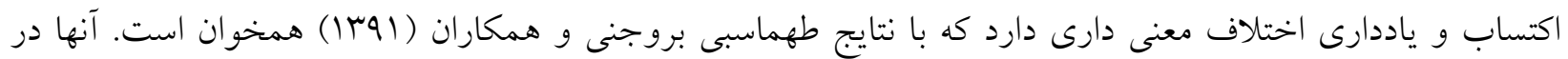
يزٔوهش خود به بررسى تاثير تمرين ذهنى بتلبٍ و سنتى بر تعادل دانشجويان برداختند و در پايان بيان كردند تمرين ذهنى يتلٍ نسبت به تمرين ذهنى سنتى و فيزيكى تاثير بيشترى بر تعادل ايستا دارد (ع|). همجنين با نتايج تحقيق رايت و

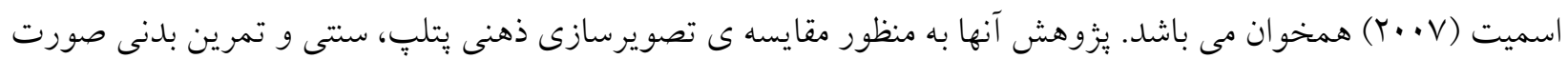

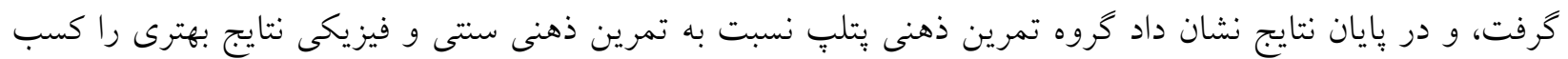

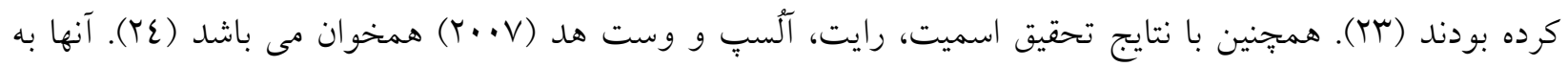
مقايسه تاثير تمرين ذهنى يتلٍ و تمرين ذهنى سنتى بر مهارت يرش خرك زيمناستيك يرداختند و نتيجه گرفتند كه گروه

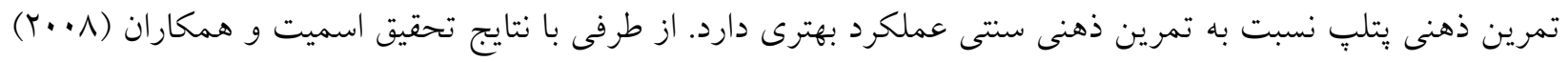

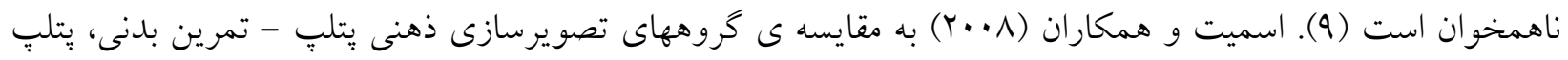
به تنهايى، تمرين بدنى به تنهايى و كنترل درتكليف ضربه كلف گيرداختند. در اين يزوهش، هر گروه دوبار در هفته به 


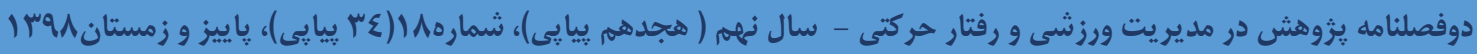

مدت شش هفته تمرين مى كرد و در بايان بيان كردند بين تصويرسازى يتلٍٍ و تمرين بدنى تفاوت معنى دارى مشاهده

يكى از دلايل اثركذارى بيشتر تصوير سازى يتلٍٍ را بر اساس نظريه يردازش اطلاعات مى توان ماهيت كاركردى اين نوع تصوير سازى دانست؛ همجنين انتظار مى رود با تصويرسازى براساس نظريه بيرامونى مسيرهاى عصبى از طريق اجراى حركتى به صورت يتلٍٍ به طور كامل فعال شده باشند و احتمالا به همين خاطر نسبت به تمرين ذهنى سنتى و تمرين بدنى موجب برترى شده است.

همجنين نتايج نشان داد كه گروه فيزيكى نسبت به گروه تمرين ذهنى سنتى داراى اختلاف معنى دار در دو مرحله اكتساب

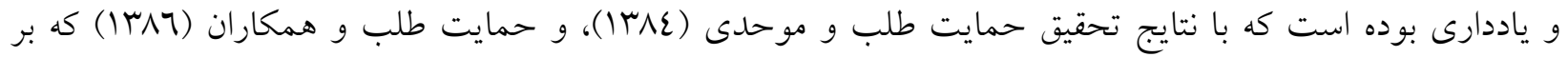

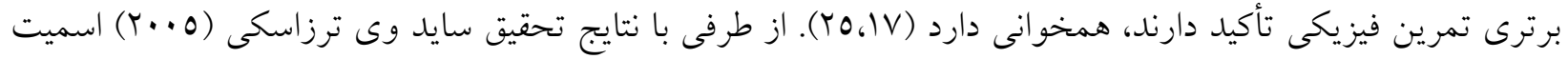

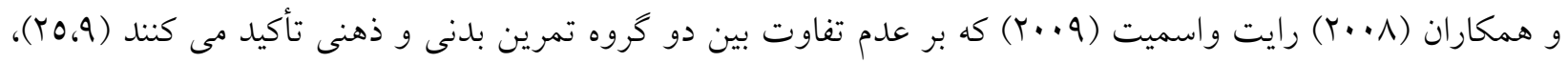

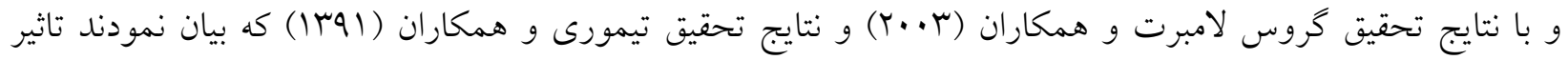
تمرين ذهنى از تمرين بدنى بيشتر است، ناهمخوان است (YV،TY).

از دلايل احتمالى اين تناقضات مى توان به متفاوت بودن مهارت هاى ملاكى و سن آزمودنى ها و توانايى تصويرسازى افراد اشاره كرد، جنانجه تجزيه و تحليل درسيكل ( 1992) نشان داد توانايى تصويرسازى ذهنى مهم ترين عامل در اثربخشى تمرين ذهنى كزارش شده است، ضمن اينكه قدرت تأثير تمرين ذهنى با كذشت زمان كاهش بيدا مى كند (YN). علاوه براين، انجام بيش از حد تمرين ذهنى سبب كاهش تمركز فرد شده و جون فرد از نتايج كار و فعاليت خود مطلع نمى شود، به مرور به حالت خود محدودى مى رسد كه به كاهش تاثير تمرين ذهنى روى يادگيرى منجر مى شود. بنابر يافته هاى اين يزوهش، شايد بتوان به منظور كاهش هزينه هاى هنخفت در ورزش و آموزش از روش تصويرسازى ذهنى يتلٍٍ به جاى تمرين بلدنى در قسمت هاى آغازين آموزش استفاده كرد. همجنين مى توان در مواقعى كه امكان استفاده از تمرين بلدنى وجود ندارد از تمرين ذهنى بِّلِ را مورد استفاده قرار داد. لذا بِيشنهاد مى شود كه مربيان و

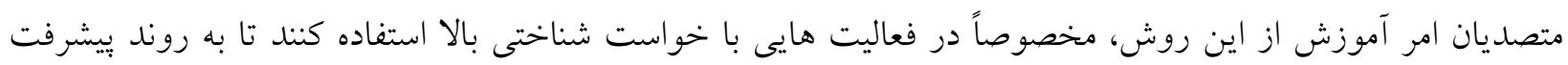
افر اد سرعت بخشند. در فعاليت هاى صرفاً حركتى مى توان از اين تصويرسازى ذهنى به عنوان مكمل تمرين بدنى استفاده كرد. همجنين بيشنهاد مى شود كه در تحقيقات آينده به بررسى و مقايسه ى تفاوت هاى جنسيتى، سطح مهارت آزمودنى ها (مبتدى و ماهر) و تكاليف با خواست شناختى و حركتى متفاوت برداخته شود.

اين مقاله بركرفته از بايان نامه كارشناسى ارشد اينجانب مى باشد. بدين وسيله از تمامى افرادى كه در اين تحقيق با ما همكارى كردند كمال تقدير و تشكر را دارم. 
I.Schmidt, R. A., \& Wrisberg, C. A. (2004). Motor learning and performance.

r. Adams, J. A. (1986). Use of the model's knowledge of results to increase the observer's performance. Journal of Human Movement Studies, 12(2), 89-98.

r. خادمى كلانترى، خسرو. داودى، نسرين (1) (1). بررسى تأثير تمرينات ذهنى بر ميزان فعاليت عضلات شانه. فصلنامه علمى طبى

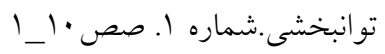

ะ. McMorris, T. (2014). Acquisition and performance of sports skills. John Wiley \& Sons.

๑. Sackett, R .S. (1934) The Infduences of Symbolic Rehearsal Upon the Retention of a Maze Habit . Journal of General Psychology . 13, 113, 128

7. Holmes, P. S., \& Collins, D. J. (2001). The PETTLEP approach to motor imagery: A functional equivalence model for sport psychologists. Journal of Applied Sport Psychology, 13(1), 60-83.

$\vee$. Whetstone, T. S. (1995). Enhancing psychomotor skill development through the use of mental practice.

^. Wakefield, C. J., \& Smith, D. (2009). Impact of differing frequencies of PETTLEP imagery on netball shooting performance. Journal of imagery research in sport and physical activity, 4(1).

१. Smith, D., Wright, C. J., \& Cantwell, C. (2008). Beating the bunker: The effect of PETTLEP imagery on golf bunker shot performance. Research quarterly for exercise and sport, 79(3), 385391.

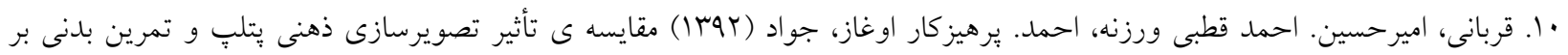

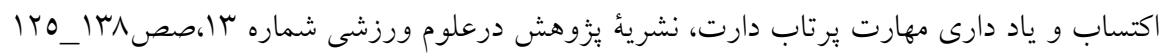

$$
\begin{aligned}
& \text { 11. زمانى ثانى، سيد حجت. فارسى، عليرضا. عبدلى، بهروز (Y (1) ). تاثير سرعت هاى مختلف تصويرسازى حركتى بر دريبل فوتبال در بازيكنان }
\end{aligned}
$$

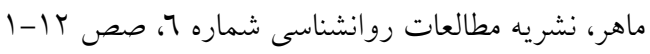

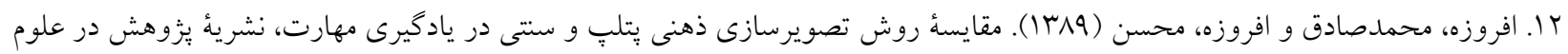

$$
\begin{aligned}
& \text { ورزشى، شماره 7، صص 19_0. }
\end{aligned}
$$

1т. Wright, C. J., \& Smith, D. (2009). The effect of PETTLEP imagery on strength performance. International Journal of Sport and Exercise Psychology, 7(1), 18-31.

$$
\begin{aligned}
& \text { ع ا. طهماسبى بروجنى، شهرزاد. بيخم قدس مير حيدرى، صنم (1) (1). تاثير مدل هاى مختلف تصويرسازى بر تعادل دانشجويان دختر دانشخاه }
\end{aligned}
$$

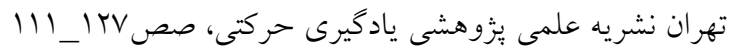

$$
\begin{aligned}
& \text { 10. سهرابى، مهاى . فارسى، عليرضا. فولاديان، جواد. (ITMM) "تعيين اعتبار و وبايائى يرسشنامه توانائى تصويرسازى تجديد نظر شده" طرح } \\
& \text { يُزوهشى، يُزوهشكده تربيت بدنى وزارت علوم تحقيقات وفناورى. }
\end{aligned}
$$




$$
\begin{aligned}
& 17 \text { ا. حمايت طلب رسول. شيخ محمود. موحدى احمدرضا. اسد محمدرضا. تأثير تقدم و تاخر تمرين ذهنى بر يادگيرى يكى مهارت ادراكى }
\end{aligned}
$$

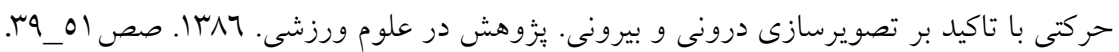

$$
\begin{aligned}
& \text { VI ا. موحدى، احمدرضا. عشايرى، حسن. باقرزاده، فضل اله. حمايت طلب، رسول (1/17). بررسى تأثير تمرين بر دو نوع محيط انخيزشى (زياد } \\
& \text { و كم) بر اجرا و يادگيرى يك تكليف ادراكى حركتى. }
\end{aligned}
$$

1^. Ryan ED. Simons. J.(1981), efficacy of imagery in enhancing mental rehearsal of skills. J. sport psychology, 4:PP:41-51.

19. Mulder T. Zijlstra S, Zijlstra W, Hochstenbach J (2004). The role of motor imagery in learning a totally mental training during residential squad training in conmbat sport Apolish experience, The sport psychologist, 9: PP:164-168.

$r \cdot$. Nowicki D (1995). Using mental training during residential squad training in conmbat sport :Apolish experience, The sport psychologist, 9: PP:164-168.

$$
\begin{aligned}
& \text { اY. جعفرى، حسن (IrAV) تأثير تمرين ذهنى مكمل تمرين عملى بر يادگيرى مهارت حركتى منتخب كره كوهنوددى. بايان نامه كارشناسى } \\
& \text { ارشد، مركز آموزش هاى نيمه حضورى دانشخاه اروميه. }
\end{aligned}
$$

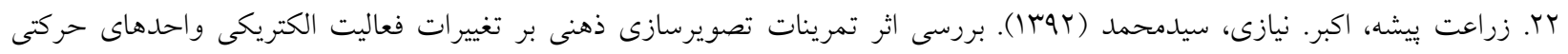

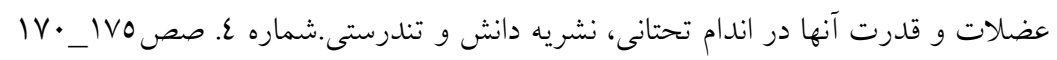

rr. Wright, C. J., \& Smith, D. K. (2007). The effect of a short-term PETTLEP imagery intervention on a cognitive task. Journal of imagery research in sport and physical activity, 2(1).

rr. Smith, Wright, Allsop \&West head, H. (2007). "It`s All in the Mind: PETTLEP-Base Imagery and Sports Performance". Journal of Applied Sport Psychology, 19(1): PP:80-92.

$$
\begin{aligned}
& \text { عَ. حمايت طلب، رسول. شيخ، محمود، باقرزاده، فضل الله. عشايرى، حسن (ع^با). تحليلى بر شيوه هاى مختلف تمرين ذهنى در اكتساب، }
\end{aligned}
$$

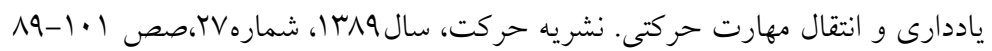

ro. Sidaway B, Trzaska AR (2005). Can mental practice increase ankle dorsiflexor torque? Phys Ther; 85(10): 1053-60.

r4. Groslambert A, Candau R, Grappe F, Dugue B, Rouillon JD (2003). Effects of autogenic and imagery training on the shooting performance in biathlon. Res Q Exerc Sport ; 74(3): 337-41.

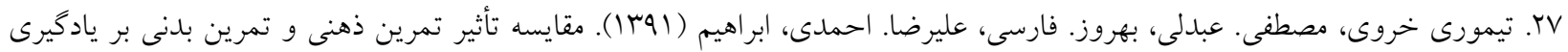

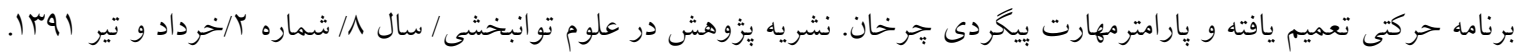

r^. Driskell, J. E., Copper, C., \& Moran, A. (1994). Does mental practice enhance performance?. Journal of Applied Psychology, 79(4), 481. 